Mohsen Ghobadi ${ }^{1}$

Department of Finance, Dehaghan Branch,

Islamic Azad University, Iran

Maryam Ghobadi²

Department of Economic,
SCIENTIFIC REVIEW ARTICLE

doi:10.5937/ekonomika1504167G

Received: August 04, 2015

Accepted: October 08, 2015

Isfahan (Khorasgan) Branch, Islamic Azad University, Iran

\title{
COMPARING ABNORMAL RETURNS AND RANKING OF TECHNICAL ANALYSIS INDICATORS BASED ON TOPSIS TECHNIQUE
}

\begin{abstract}
This paper is about using TOPSIS technique for ranking of investment based on technical analysis indicators. Sample data Include; 10 listed Dow-Johns companies, Yahoo, Facebook, Google, Apple, Microsoft, General Electric, Coca Cola, Cisco, Boeing and Bank of America. "between beginnings of 2009 to the end of 2014". In addition, it presents a Technique for Order of profitability by Similarity to Ideal Solution to evaluate technical indicators. Consequently, by this ranking we can determine the relative importance of indicators to make the best investment decision. According to results, all the technical analysis indicators, which used in this research, can find profitable trading prices and all the returns are more than zero. The summary of results for this sub-period describe that in order, MACD with a mean of (1), RSI with a mean of (0.69), SMA with mean of (0.54), STO with a mean of (0.52), CCI with a mean of (0.36) and MFI with a mean of (0), everyone has an abnormal return greater than the average market return rate with a mean of 0.014 .
\end{abstract}

Key words: Technical Analysis Indicators; TOPSIS Technique; Profitability Ranking;

JEL classification: G11, G17, C02

\section{ПОРЕЂЕНЕ АБНОРМАЛНОГ ВРАЋАЊА И РАНГИРАЊА ТЕХНИЧКЕ АНАЛИЗЕ ИНДИКАТОРА НА ОСНОВУ TOPSIS TECHNIQUE}

\begin{abstract}
Апстракт
У овом раду је коришћена Tорsis Tесhniquе за рангирање инвестиције на основу индикатора техничке анализе. Узорак података укључује; 10 наведених Dow-Johns-компанија, Yahoo, Facebook, Google, Apple, Microsoft, General Electric, Coca Cola, Cisco, Boeing and Bank of America y nерuодy od

\footnotetext{
${ }^{1}$ ghobadi1989@yahoo.com

2 ghobadi1368@gmail.com
} 
почетака 2009. године до краја 2014. године. Поред тога, представља технику за одређивање профитабилности по сличности са идеалним решењем за процену техничких показатеља. Сходно томе, овој листи можемо одредити релативни значај показатеља која је најбоља инвестициона одлука. Према резултатима, код свих показатеља техничке анализе, који се користе у овом истраживању, могу се наћи профитабилне иуене трговања и све ито се враћа је више од нуле. Резиме резултата за овај под период описујемо следећим редом, MACD са средњом вредношчу (1), RSI са средюом вредношћу (0.69), SMA са средњом вредношћу (0.54), STO са средњом вредношћу (0.52), CCI са средњом вредношћу (0.36) и MFI са средюом вредношћу (0), сваки има абнормални повратак већи од просечне стопе на тржишту са средюом вредношћу 0.014.

Кључне речи: техничка анализа индикатора; TOPSIS Technique; Профитабилност Рангирање;

\section{Introduction}

The multi-criteria decision-making method is a common replication applied in Operations Management, which is then modified to be applied in Financial Management scope. The first research in Financial Management done by Tarmizi in Indonesia. Therefore, this method is relatively new in Financial Management. The modification is done by changing the criteria used in operations field into financial ratio criteria. The application of statistical factors in this multi-criteria decision-making method is still considered trial. Thus, there has been no established financial criterion applied for this method until nowadays. Simultaneous research can be expected to develop some useful criteria, which can be a fundamental in stock selection method, as well as a new method in the Financial Management scope. (Tarmizi, 2006).

The complexities are numerous, and overcoming these complexities to offer successful selections is a technical analyst's challenge. It is important that the limited amount of investing Portfolio should be efficiently allocated over many stocks. The technical analysts need to forecast future prices to reduce the average market return rates and find optimal combination of optimal indicators out of many technical indicators. The purpose of technical analysts is maximizing the returns in allocating indicators Importance to many indicators.

In a theories problem, the solution of the portfolio selection problem presented by H.Markowitz has a tendency to increase the number of stocks selected for investors. (Markowitz, 1952).

This paper explores which indicator, including the Relative Strength Index; Stochastic Oscillator; Simple Moving Average; Money Flow Index; Commodity Channel Index has optimal trading ability can lead to high financial performance. The financial performance is evaluated by TOPSIS multi-criteria decision-making (MCDM); this information could support technical analysts' decision- making. In real investment systems, the decision-making problems are very often uncertain or vague in a number of ways. This type of uncertainty has long been handled appropriately by probability 
theory and statistics. However, in many areas of financial problems, such as investment management, market microstructure, financing and others decisions often employ natural language to express thinking and subjective perception.

Multi-criteria decision-making forms an important part of the decision process for both the small (an individual) and the large (an organization) investment. When available financial information is precise, many methods exist to evaluate the investment. The methods used to analyze securities and make investment decisions fall into two very broad categories: fundamental analysis and technical analysis. Fundamental analysis involves analyzing the characteristics of a company in order to estimate its value. Technical analysis takes a completely different approach; it does not care one bit about the "value" of a company or a commodity. Technicians are only interested in the price movements in the market. Technical analysis is a method of evaluating securities by analyzing the statistics generated by market activity, such as past prices and volume. Technical analysts do not care whether a stock is undervalued - the only thing that matters is a security's past trading data and what information this data can provide about where the security might move in the future. These days by improvement in financial and computer Technology one of the ways that investors extensively use is technical analysis. One of advantage of Technical analysis is finding the best trading price. Finding these trading prices, help the investors that trade timely and consecutively in the markets by increasing and decreasing the prices speculation and in a period earn abnormal returns.

\section{Theoretical and background research Technical analysis}

Fluctuations in stock markets has made imperative to understand the concept and application of Technical Analysis Indicator. Researcher hereby defined Technical Analysis Indicator as series of data points that are derived by applying a formula to the security's price and/or volume fields.

So researchers need the price data that is the OHLC (Open-High-Low-Close). A series of data points over a period of time is required to create valid reference points to enable technical analysis. (Ghobadi, 2014).

Technical Analysis Indicators is sub-divided into Leading Indicators and Lagging Indicators. These indicators help in profit by predicting what prices will do next and thus provides greater rewards at the expense of increased risks. So such indicator precedes the price movements. They perform best in sideways or trading market. Such indicators typically work by measuring how overbought or oversold a security is because the security which is oversold will bounce back.

Technical Analysis: The Technical Analysis origins back to Charles Dow research in early twentieth on industrials Dow Jones Averages index. His research on the market caused him realize that market trends and speculations do not simply follow financial statements and information and there are some other factors that affect the market. Those researches made a great development on the markets price forecast methods. Dow Theory made by collection of his articles in Wall-street journals "between (1851) to (1902)".

The Dow Theory on stock price movement is a form of technical analysis that includes some aspects of sector rotation and his theory mainly focused on market trends Dow Theory basis conclude that the fact prices are affected by all the information and 
events in the markets. All the available knowledge to market participants, including investors or fund managers affects in the price. Early attempts in academic councils assess the effectiveness of technical analysis considered very simple rules called filter rules. These rules involve buying a security if it had increased by $\mathrm{x} \%$ on the last period or selling it if its price has decreased by $\mathrm{x} \%$ on the last period. (Ghobadi, 2014).

Frankel and Froot noted that market professionals tend to include Technical Analysis in forecasting the market( Frankel. Froot, 1990). Their article discussed that the helpful principle of Technical Analysis is to identify trends and then go with the trend whether it is occurring randomly or due to fundamental factors. They also discussed the techniques of moving averages and relative strength index (RSI) by applying it on Singapore stock exchanges. Their results showed that application of RSI is good if used in non-trending environment and the results indicate that using simple moving averages and 50 crossover method of RSI will provide good results excluding the transaction costs. Manuel Ammann, Matthias Rekate and Rico Von Wyss The text of their article showed an outperformance of Technical Analysis. They argued that the extent of academic acceptance of using Technical Analysis is not so good as compared to its practical application and it has been said that Technical Analysis is combination of separate methods than a full proper system or method. The article also discussed that Technical Analysis is connected with the forces of demand and supply and sentiments in markets so it is very useful in short term also because Technical Indicators can be calculated and applied quickly whereas fundamental techniques may take days to apply (Wong. Manzur. Chew, 2002). They also discussed simple moving average techniques, RSI and advance/decline ratios technique and applied it onto 18 stocks out of the Swiss Stock market and concluded that application of Technical Analysis including transaction costs provides results not more than a buy or hold strategy but advance/decline ratios are more helpful and successful even when transaction costs are taken into account. They show that support and resistance levels coincide with peaks in depth on the limit order book 1 and moving average forecasts reveal information about the relative position of depth on the book (Kavajecz. White, 2004).

Treynor and Ferguson established the first theoretical model to apply Technical Analysis and model described that investors choose strategies to hold a security for a particular time period either long or short in order to get benefit from it later after they receive private information at particular point of time. The model concluded that this private information is helpful only with the combination of some additional or further information. (Treynor. Ferguson, 1985).

Brown and Jennings in the article on outperformance of Technical Analysis said that portfolio strategies works so well when the market does not contain all relevant information and there are only few investors who are well aware of that information. (Brown. Jennings, 1989) .

William Brock, Josef Lakonishok and Blake LeBaron (1992) their article explored moving averages and support and resistance levels in order to find out generation of signals for the long and short time period and then to check high and low hits of prices. They argued that we cannot allow to leave those false patterns which are not covered by Technical Analysis tools and Techniques because it is very difficult to enquire too much about data but we can be able to reduce this problem either by providing full reporting of techniques used or by using a very long data and information. (Brock. Lakonishok. LeBaron, 1992).

Dunham the text of their article explained the theoretical and empirical examination of price trends and patterns in Technical Analysis. Technical Analysis has been defined in the Article as to use information from the past price trends and movements which are 
then summarized into charts which then helps investors to predict price movements in future. (Dunham, 2007).

Kadida Ramadhani \& Shagilla Mashaushi the text of their article showed the analysis of technical trading strategies. In the 1980s, technical strategies have made a significant "come back" for predictions and it motivated researchers to reconsider Technical Analysis as well. Louis B. Mendelsohn argued that the technique used in trend forecasting is moving averages. It has its own strengths and weaknesses at smoothing the data and reducing the lag (when mathematical structure or in simple words averaging prices over a number of prior periods), have a tendency to follow the current market price) and this lag effect can become very prominent and costly in very fast moving markets where prices are rising and falling sharply, If this deficiency can be overcome in some way then this tool of moving averages could be ranked as the most effective trend identification indicator in the analysis of market but still despite of all its limitations Moving Average technique has still been used broadly because it has been recognized as an important quantitative trend reorganization technique and if investors are creating such strategies for forecasting trends that compares actual moving averages with predicted moving averages, then definitely investors will be able to get an early warning that there is an approaching change in trend direction. (Ramadhani. Mashaushi, 2006).

Ghobadi in a his thesis about "Profitability of Technical Analysis Strategy to Earn Abnormal Returns in TSE (2007-2013)" report abnormal returns using technical trading strategy in the Tehran Stock Exchange by statistical tests. They note that Technical Analysis can signal optimal trading prices and give Abnormal returns more attractive than the Iran Average market return Rate. (Ghobadi, 2014).

Ghobadi test the Profitability of Technical Analysis Indicators to Earn Abnormal Returns in International Exchange Markets from 2008 through 2013. They conclude that the positive returns according to technical analysis indicator returns and these returns is significantly more than London Interbank Offered Rate. They observe that the Stochastic Oscillator, Relative Strength Index, Money Flow Index, Commodity Channel Index, Simple Moving Average indicators produces the best results, followed by the London Interbank Offered Rate. (Ghobadi, 2014).

Ben R Marshall and Jared M. Cahan evaluated the profitability of CRISMA technical trading system. They collect information of companies on CRSP database in the period of January1, 1976 to December31, 2003 including 200 days of past closing prices and 20 days of past volume. They examine both long and short CRISMA filter rules in this study and found that even the system generates some profit but not consistently. (Marshall. Cahan, 2006).

\section{Topsis}

The Technique for Order of Preference by Similarity to Ideal Solution (TOPSIS) is a multi-criteria decision analysis method, which was originally develop by Hwang and Yoon in 1981 with further developments by Yoon and Hwang, Lai and Liu. TOPSIS is based on the concept that the chosen alternative should have the shortest geometric distance from the positive ideal solution and the longest geometric distance from the negative ideal solution. It is a method of compensatory aggregation that compares a set of alternatives by identifying weights for each criterion. Normalizing scores for each 
criterion and calculating the geometric distance between each alternative and the ideal alternative, which is the best score in each criterion. (Yoon, 1987 : Hwang. Lai. Liu, 1993).

An assumption of TOPSIS is that the criteria are monotonically increasing or decreasing. Normalization is usually required as the parameters or criteria are often of incongruous dimensions in multi-criteria problems.

Lehmann and Modest combined the APT performance evaluation method with the Treynor and Mazuy (1966) quadratic regression technique. They found statically significant measured abnormal timing and selectivity performance by mutual funds. They also examined the impact of alternative benchmarks on the performance of mutual funds finding that performance measures are quite sensitive to the benchmark chosen and finding that a large number of negative selectivity measures. In addition, Henriksson (1984) found a negative correlation between the measures of stock selection ability and market timing. (Lehmann. Modest, 1987).

Lee and Rahman empirically examine market timing and selectivity performance of mutual funds. It is important that fund managers be evaluated by both selection ability and market timing skill. (Lee. Rahman, 1990).

Sugeno introduced the concept of fuzzy measure and fuzzy integral, generalizing the usual definition of a measure by replacing the usual additive property with a weak requirement, i.e. the monotonic property with respect to set inclusion. In this section, we give a brief to some notions from the theory of fuzzy measure and fuzzy integral. (Sugeno, 1974).

\section{Research Hypothesis}

1. Technical analysis indicators can forecast profitable investment.

$H_{0}: \mu>0$

$H_{1}: \mu \leq 0$

2. From TOPSIS technique point of view, which technical analysis indicator returns priority is higher?

$H_{0}: \mu_{1}=\mu_{2}=\ldots=\mu_{k}$, i.e., all indicator return means are equal.

$H_{A}:$ At least two of the means differ.

Variables

Relative Strength Index

100

1.RSI $=100-$

$$
1+R S
$$

2.RS = Average Gain / Average Loss

3. Average Gain = [(previous Average Gain $) \times 13+$ current Gain] / 14

4.Average Loss $=[($ previous Average Loss $) \times 13+$ current Loss $] / 14$ 
The Relative Strength Index (RSI) is a momentum oscillator that measures the speed and change of price movements. RSI oscillates between 0 and 100 . Traditionally, and according to Wilder, RSI considered overbought when above 70 and oversold when below 30. Signals can also be generate by looking for divergences, failure swings and centerline crossovers. RSI can also use to identify the general trend. RSI considered overbought when above 70 and oversold when below 30. These traditional levels can also adjust to fit the security or analytical requirements. Rising overbought to 80 or lowering oversold to 20 will reduce the number of overbought/oversold readings. Short-term traders sometimes use 2-period RSI to look for overbought readings above 80 and oversold readings below 20 .

\section{Stochastic Oscillator (STO)}

$$
\begin{aligned}
& 1 . \% K=(\text { Current Close }- \text { Lowest Low }) /(\text { Highest High }- \text { Lowest Low }) * 100 \\
& 2 . \% D=3-\text { day SMA of } \% K
\end{aligned}
$$

\section{Lowest Low $=$ lowest low for the look - back period}

\section{Highest High = highest high for the look - back period}

\section{5.\%K is multiplied by 100 to move the decimal point two places}

Developed by George C. Lane in the late 1950s, the Stochastic Oscillator is a momentum indicator that shows the location of the close relative to the high-low range over a set number of periods. According to an interview with Lane, the Stochastic Oscillator “doesn't follow price, it doesn't follow volume or anything like that. It follows the speed or the momentum of price. As a rule, the momentum changes direction before price." As such, bullish and bearish divergences in the Stochastic Oscillator can be used to foreshadow reversals. Lane identified this first, and most important, signal. Lane also used this oscillator to identify bull and bear set-ups to anticipate a future reversal. Because the Stochastic Oscillator is range bound, is also useful for identifying overbought and oversold levels. The Stochastic Oscillator measures the level of the close relative to the high-low range over a given period. Assume that the highest high equals 110, the lowest low equals 100 and the close equals 108. The high-low range is 10 , which is the denominator in the $\% \mathrm{~K}$ formula. The close less the lowest low equals 8 , which is the numerator. 8 divided by 10 equals .80 or $80 \%$. Multiply this number by 100 to find $\% \mathrm{~K}$ $\% \mathrm{~K}$ would equal 30 if the close were at $103(.30 \times 100)$. The Stochastic Oscillator is above 50 when the close is in the upper half of the range and below 50 when the close is in the lower half. Low readings (below 20) indicate that price is near its low for the given time period. High readings (above 80 ) indicate that price is near its high for the given time period. The IBM example above shows three 14-day ranges (yellow areas) with the closing price at the end of the period (red dotted) line. The Stochastic Oscillator equals 91 when the close was at the top of the range. The Stochastic Oscillator equals 15 when the close was near the bottom of the range. The close equals 57 when the close was in the middle of the range. 


\title{
Simple Moving Average (SMA)
}

\author{
1.Daily Closing Prices : 11,12,13,14,15,16,17 \\ 2.First day of 5 - day SMA : $(11+12+13+14+15) / 5=13$ \\ 3. Second day of 5 - day SMA : $(12+13+14+15+16) / 5=14$ \\ 4.Third day of 5 - day SMA : $(13+14+15+16+17) / 5=15$
}

A simple moving average is formed by computing the average price of a security over a specific number of periods. Most moving averages are based on closing prices. A 5-day simple moving average is the five-day sum of closing prices divided by five. As its name implies, a moving average is an average that moves. Old data is dropped as new data comes available. This causes the average to move along the time scale. Below is an example of a 5-day moving average evolving over three days. The first day of the moving average simply covers the last five days. The second day of the moving average drops the first data point and adds the new data point. The third day of the moving average continues by dropping the first data point and adding the new data point. In the example above, prices gradually increase from 22.2 to 24 over a total of seven days. Notice that the moving average also rises from 22.4 to 23.6 over a threeday calculation period. Also, notice that each moving average value is just below the last price.

\section{Money Flow Index}

\section{Typical Price $=($ High + Low + Close $) / 3$}

2.Raw Money Flow $=$ Typical Price $\times$ Volume

\section{Positive Money Flow = Sum of positive Raw Money Flow over 14 periods.}

4.Negative Money Flow = Sum of negative Raw Money Flow over 14 periods.

\section{Money Flow Ratio = $($ Positive Money Flow $) /($ Negative Money Flow $)$}

\section{Money Flow Index = $100-100 /(1+$ Money Flow Ratio $)$}

The Money Flow Index (MFI) is an oscillator that uses both price and volume to measure buying and selling pressure. Created by Gene Quong and Avrum Soudack, MFI is also known as volume-weighted RSI. MFI starts with the typical price for each period. Money flow is positive when the typical price rises (buying pressure) and negative when the typical price declines (selling pressure). Typically, MFI above 80 is considered overbought and MFI below 20 is considered oversold. Strong trends can present a problem for these classic overbought and oversold levels. MFI can become overbought $(>80)$ and prices can simply continue higher when the uptrend is strong. Conversely, MFI can become oversold $(<20)$ and prices can simply continue lower when the downtrend is strong. Quong and Soudack recommended expanding these extremes further qualify signals. A move above 90 is truly overbought and a move below 10 is 
truly oversold. Moves above 90 and below 10 are rare occurrences that suggest a price move is unsustainable.

\title{
Commodity Channel Index
}

\author{
1.CCI $=($ Typical Price $-20-$ period SMA of TP $) /(.015 \times$ Mean Deviation $)$ \\ 2.Typical Price $($ TP $)=($ High + Low + Close $) / 3$

\section{Constant $=.015$}

Developed by Donald Lambert and featured in Commodities magazine in 1980, the Commodity Channel Index (CCI) is a versatile indicator that can use to identify a new trend or warn of extreme conditions. Lambert originally developed CCI to identify cyclical turns in commodities, but the indicator can successfully applied to indices, ETFs and other securities. In general, CCI measures the current price level relative to average price level over a given period. CCI is relatively high when prices are far above their average. CCI is relatively low when prices are far below their average. In this manner, $\mathrm{CCI}$ can use to identify overbought and oversold levels. As noted above, the majority of $\mathrm{CCI}$ movement occurs between -100 and +100 . A move that exceeds this range shows unusual strength or weakness that can foreshadow an extended move. Think of these levels as bullish or bearish filters. Technically, CCI favors the bulls when positive and the bears when negative. However, using a simple zero line crossovers can result in many whipsaws. Although entry points will lag more, requiring a move above +100 for a bullish signal and a move below -100 for a bearish signal reduces whipsaws.

\section{Data}

This paper applies this process to 10 listed Dowjohns companies for evaluation, namely, Yahoo, Facebook, Google, Apple, Microsoft, General Electric, Coca Cola, Cisco, Boeing and Bank of America. Data include 13200 daily prices "between (2009) to (2014)".

\section{Research Methodology}

1. T-Test: It can use to determine if two sets of data are significantly different from each other, and is most commonly apply when the test statistic would follow a normal distribution if the value of a scaling term in the test statistic known.

$$
t=\frac{\bar{y}_{1}-\bar{y}_{2}}{\sqrt{s_{y}{ }^{2}\left(1 / n_{1}+1 / n_{2}\right)}}
$$


2. TOPSIS: TOPSIS based on the concept that the chosen alternative should have the shortest geometric distance from the positive ideal solution and the longest geometric distance from the negative ideal solution

Step 1: Calculate the normalized decision matrix. The normalized value $r_{i j}$ is calculated as follows:

$$
r_{i j}=x_{j} \sqrt{\sum_{i-1}^{m} x_{j}^{2}} \mathrm{i}=1,2, \ldots, \mathrm{m} \text { and } \mathrm{j}=1,2, \ldots, \mathrm{n} \text {. }
$$

Step 2: Calculate the weighted normalized decision matrix. The weighted normalized value $\mathcal{V}_{\boldsymbol{j}}$ is calculated as follows:

$$
\boldsymbol{v}_{i j}=\boldsymbol{r}_{j} \times \boldsymbol{W}_{j} \mathrm{i}=1,2, \ldots, \mathrm{m} \text { and } \mathrm{j}=1,2, \ldots, \mathrm{n} \text {. }
$$

Where $\mathcal{W}_{j}$ is the weight of the $j^{h}$ criterion or attribute and $\sum_{j=1}^{n} \mathcal{W}_{j}=1$.

Step 3: Determine the ideal ( $\left.A^{*}\right)$ and negative ideal ( $\left.A^{-}\right)$solutions.

$$
\begin{aligned}
& A^{*}=\left\{\left(\max _{i} v_{i j} \mid j \in C_{b}\right),\left(\min _{i} v_{i j} \mid j \in C_{c}\right)\right\}=\left\{v_{j}^{*} \mid j=1,2, \ldots, m\right\} \\
& A^{-}=\left\{\left(\min _{i} v_{i j} \mid j \in C_{b}\right),\left(\max _{i} v_{i j} \mid j \in C_{c}\right)\right\}=\left\{v_{j}^{-} \mid j=1,2, \ldots, m\right\}
\end{aligned}
$$

Step 4: Calculate the separation measures using the m-dimensional Euclidean distance. The separation measures of each alternative from the positive ideal solution and the negative ideal solution, respectively, are as follows:

$$
\begin{aligned}
& S_{i}^{*}=\sqrt{\sum_{j=1}^{m}\left(v_{j}-v_{j}^{*}\right)^{2}, j=1,2, \ldots, m} \\
& S_{i}^{-}=\sqrt{\sum_{j=1}^{m}\left(v_{j}-v_{j}^{-}\right)^{2}, j=1,2, \ldots, m}
\end{aligned}
$$

Step 5: Calculate the relative closeness to the ideal solution. The relative closeness of the alternative $A_{i}$ with respect to $A^{*}$ is defined as follows:

$$
R C_{i}^{*}=\frac{S_{i}^{-}}{S_{i}^{*}+S_{i}^{-}}, i=1,2, \ldots, m
$$


Step 6: Rank the preference order.

\begin{tabular}{|c|c|c|c|c|c|c|}
\hline & ST.D & NT & NF & MIN & MAX & MEAN \\
\hline RSI & 0.0045 & 357 & 142 & -0.042 & 0.797 & $\mathbf{0 . 5 5}$ \\
\hline CCI & 0.0041 & 400 & 306 & -0.033 & 1.19 & $\mathbf{0 . 5 2}$ \\
\hline MFI & 0.0057 & 277 & 159 & -0.031 & 0.854 & $\mathbf{0 . 4 6}$ \\
\hline SMA & 0.0048 & 320 & 135 & -0.036 & 0.601 & $\mathbf{0 . 4 7}$ \\
\hline MACD & 0.0047 & 223 & 120 & -0.031 & 0.549 & $\mathbf{0 . 4 8}$ \\
\hline STO & 0.0039 & 418 & 203 & -0.029 & 1.28 & $\mathbf{0 . 5 9}$ \\
\hline & MIN & MAX & MIN & MAX & MAX & MAX \\
\hline WEIGHTS & 1 & 1 & 1 & 1 & 1 & $\mathbf{1}$ \\
\hline IDEAL & 0.0039 & 418 & 120 & -0.029 & 1.28 & $\mathbf{0 . 5 9}$ \\
\hline THE WORST & $\mathbf{0 . 0 0 5 7}$ & $\mathbf{2 2 3}$ & $\mathbf{3 0 6}$ & $\mathbf{- 0 . 0 4 2}$ & $\mathbf{0 . 5 4 9}$ & $\mathbf{0 . 4 6}$ \\
\hline
\end{tabular}

We use T-Test statistical criteria for ranking and comparing Indicators

- ST.D : Standard Division

- NT : Number of True and Profitable Investment Signals

- NF : Number of False and Unprofitable Investment Signals

- MIN : Minimum Rate of Return

- MAX : Maximum Rate of Return

- MEAN : Average Rate of Return

\begin{tabular}{|c|c|c|c|c|c|c|}
\hline & ST.D & NT & NF & MIN & MAX & MEAN \\
\hline RSI & 0.0012 & -134 & 164 & 0 & -0.248 & $\mathbf{- 0 . 0 9}$ \\
\hline CCI & 0.0016 & -177 & 0 & -0.009 & -0.641 & $\mathbf{- 0 . 0 6}$ \\
\hline MFI & 0 & -54 & 147 & -0.011 & -0.305 & $\mathbf{0}$ \\
\hline SMA & 0.0009 & -97 & 135 & -0.006 & -0.052 & $\mathbf{- 0 . 0 1}$ \\
\hline MACD & 0.001 & 0 & 186 & -0.011 & 0 & $\mathbf{- 0 . 0 2}$ \\
\hline STO & 0.0018 & -195 & 103 & -0.013 & -0.731 & $\mathbf{- 0 . 1 3}$ \\
\hline NORMA & $\mathbf{0 . 0 0 3 0 0 8 3}$ & $\mathbf{3 1 5 . 6 5 0 1 2}$ & $\mathbf{3 3 4 . 5 6 6 8 8}$ & $\mathbf{0 . 0 2 2 9 7 8 3}$ & $\mathbf{1 . 0 4 9 9 8 8 1}$ & $\mathbf{0 . 1 7 0 5 8 7 2}$ \\
\hline
\end{tabular}

\begin{tabular}{|c|c|c|c|c|c|c|}
\hline \multicolumn{7}{|c|}{ NORMED MATRIX } \\
\hline & ST.D & NT & NF & MIN & MAX & MEAN \\
\hline RSI & 0.3988935 & -0.4245207 & 0.490186 & 0 & -0.2361932 & $\mathbf{- 0 . 5 2 7 5 8 9 3}$ \\
\hline CCI & 0.531858 & -0.5607474 & 0 & -0.3916747 & -0.6104831 & $\mathbf{- 0 . 3 5 1 7 2 6 2}$ \\
\hline MFI & 0 & -0.1710755 & 0.439374 & -0.4787136 & -0.2904795 & $\mathbf{0}$ \\
\hline SMA & 0.2991701 & -0.3073023 & 0.4035068 & -0.2611165 & -0.0495244 & $\mathbf{- 0 . 0 5 8 6 2 1}$ \\
\hline MACD & 0.3324112 & 0 & 0.5559426 & -0.4787136 & 0 & $\mathbf{- 0 . 1 1 7 2 4 2 1}$ \\
\hline STO & $\mathbf{0 . 5 9 8 3 4 0 2}$ & $\mathbf{- 0 . 6 1 7 7 7 2 6}$ & $\mathbf{0 . 3 0 7 8 6 0 7}$ & $\mathbf{- 0 . 5 6 5 7 5 2 4}$ & $\mathbf{- 0 . 6 9 6 1 9 8 4}$ & $\mathbf{- 0 . 7 6 2 0 7 3 5}$ \\
\hline
\end{tabular}




\begin{tabular}{|c|c|c|c|c|c|c|c|c|}
\hline \multicolumn{9}{|c|}{ WEIGHTED NORMED MATRIX } \\
\hline & ST.D & NT & NF & MIN & MAX & MEAN & TOTAL & $\begin{array}{l}\text { RESULT } \\
\text { - RANK }\end{array}$ \\
\hline RSI & 0.39889 & -0.42452 & 0.49018 & 0 & -0.236193 & -0.5275893 & 0.6907586 & 2 \\
\hline CCI & 0.531858 & -0.56074 & 0 & -0.391674 & -0.610483 & -0.3517262 & 0.3655402 & 5 \\
\hline MFI & 0 & -0.17107 & 0.43937 & -0.478713 & -0.290479 & 0 & 0 & 6 \\
\hline SMA & 0.299170 & -0.30730 & 0.40350 & -0.261116 & -0.049524 & -0.058621 & 0.5420576 & 3 \\
\hline MACD & 0.332411 & 0 & 0.55594 & -0.478713 & 0 & -0.1172421 & 1 & 1 \\
\hline STO & 0.598340 & -0.61777 & 0.30786 & -0.565752 & -0.696198 & -0.7620735 & 0.5225867 & 4 \\
\hline IDEAL & 0.598340 & 0 & 0.55594 & 0 & 0 & 0 & & \\
\hline THE WORST & & -0.61777 & $\mathbf{0}$ & -0.565752 & -0.696198 & -0.7620735 & & \\
\hline
\end{tabular}

\section{Results and Conclusions}

In this paper, the aim is to rank Technical analysis indicators while considering advantages of some of the important ranking methods, existing in literature. As each of existing ranking methods have some major benefits that other do not have and the Fact that it is not possible to gather all these advantages in a united model, thus is seems significant to provide a new ranking method which considered all the good aspects of these models. In doing so, MCDM method is considered. As regards of the obtained ranking orders form deferent ranking models and a matrix of weights, corresponds to the deferent property of these methods, TOPSIS is accounted for in order to consider deferent aspects of these methods and a new Method introduced. For further research on this subject, other aspect of MCDM technique can also be accounted for in order to obtain a new ranking order on basis of the existing ranking methods.

We have to compare the returns for all the filters of each stock and the return of "average market return rate". The filter that generates the maximum return among all is calling the optimal filter for that stock. The summary of results for this sub-period is described that According to the results of the TOPSIS in order; MACD with a mean of (1), RSI with a mean of (0.69), SMA with mean of (0.54), STO with a mean of (0.52), CCI with a mean of (0.36) and MFI with a mean of (0) stand after each other's in the list.

1. MACD with a mean of (1.00)

2. RSI with a mean of $(0.69)$

3. SMA with a mean of $(0.54)$

4. STO with a mean of $(\mathbf{0 . 5 2})$

5. CCI with a mean of (0.36)

6. MFI with a mean of $(\mathbf{0 . 0 0})$

The results provided strong support for the technical indicators. According to confidence level, $\% 95$ all the technical analysis indicators used in this research can find profitable trading prices and all the returns are more than zero. 


\section{References}

Agostino, D., Arena, M., Azzone, G., Dal Molin, M., \& Masella, C. (2012). Developing a performance measurement system for public research centres. International Journal of Business Science and Applied Management, 7(1), 43-60.

Amini, M., \& Bienstock, C. C. (2014). Corporate sustainability: an integrative definition and framework to evaluate corporate practice and guide academic research. Journal of Cleaner Production, 76, 12-19.

Anooj, P. K. (2013). Implementing Decision Tree Fuzzy Rules in Clinical Decision Support System after Comparing with Fuzzy Based and Neural Network Based Systems. In IT Convergence and Security (ICITCS), 2013 International Conference on (1-6). IEEE.

Büyüközkan, G., \& Çifçi, G. (2012). A novel hybrid MCDM approach based on fuzzy DEMATEL, fuzzy ANP and fuzzy TOPSIS to evaluate green suppliers. Expert Systems with Applications, 39(3), 3000-3011.

Byers, T. H., Dorf, R. C., \& Nelson, A. J. (2011). Technology ventures: from idea to enterprise. McGraw-Hill.

Callen, J. L., Gavious, I., \& Segal, D. (2010). The complementary relationship between financial and non-financial information in the biotechnology industry and the degree of investor sophistication. Journal of Contemporary Accounting \& Economics, 6(2), 61-76. doi: 10.1016/j.jcae.2010.09.001

Cardinaels, E., \& van Veen-Dirks, P. M. (2010). Financial versus non-financial information: The impact of information organization and presentation in a Balanced Scorecard. Accounting, Organizations and Society, 35(6), 565-578. doi: 10.1016/j.aos.2010.05.003

Elleuch, J., \& Trabelsi, L. (2009). Fundamental analysis strategy and the prediction of stock returns. International Research Journal of Finance and Economics, 30(1), 95-107.

Gangurde, S. R., \& Akarte, M. M. (2013). Customer preference oriented product design using AHP-modified TOPSIS approach. Benchmarking: An International Journal, 20(4), 549-564.

Ghobadi, M., \& Abdolbaghi, A. (2014). Profitability of Technical Analysis Indicators to Earn Abnormal Returns in International Exchange Markets. ISJ Theoretical \& Applied Science, 11(19), 20-26.

Ghobadi, Mohsen. (2014). Profitability of Technical Analysis Strategy to Earn Abnormal Returns in Tehran Stock Exchange (2007-2013). M.A Thesis, Islamic Azad University, Dehaghan Branch, Iran.

Hammad Hassan Mirza, (2013), Does Investor Protection Affect Managements' Decision to Pay Dividend? Evidence from South Asia, Caspian Journal of Applied Sciences Research 2(11), 26-38.

Karimi, M., Moztarzadeh, F., Pakzad, A., Beynaghi, A., \& Mozafari, M. (2012). Application of Fuzzy TOPSIS for group decision making in evaluating financial risk management. In Innovation Management and Technology Research (ICIMTR), 2012 International Conference on (215-219). IEEE. 
Mark Andrew Lim (2014), A Handbook of Technical Analysis: The Practitioner's Comprehensive Guide to Technical Analysis, Wiley.

Popaitoon, S., \& Siengthai, S. (2014). The moderating effect of human resource management practices on the relationship between knowledge absorptive capacity and project performance in project-oriented companies. International Journal of Project Management, 32(6), 908-920.

Pring, J.M., (2009). Technical analysis. McGraw-Hill.

Carmona, R. (2014). Statistical analysis of financial data in R. New York: Springer.

Salehi, K. (2015). A hybrid fuzzy MCDM approach for project selection problem. Decision Science Letters, 4(1), 109-116.

Viskanta, T. E. (2012). Abnormal returns. McGraw-Hill.

Tan, Y. T., Shen, L. Y., Langston, C., \& Liu, Y. (2010). Construction project selection using fuzzy TOPSIS approach. Journal of modelling in management, 5(3), 302315 .

Wang, R. T., Ho, C. T. B., \& Oh, K. (2010). Measuring production and marketing efficiency using grey relation analysis and data envelopment analysis. International Journal of Production Research, 48(1), 183-199. 